
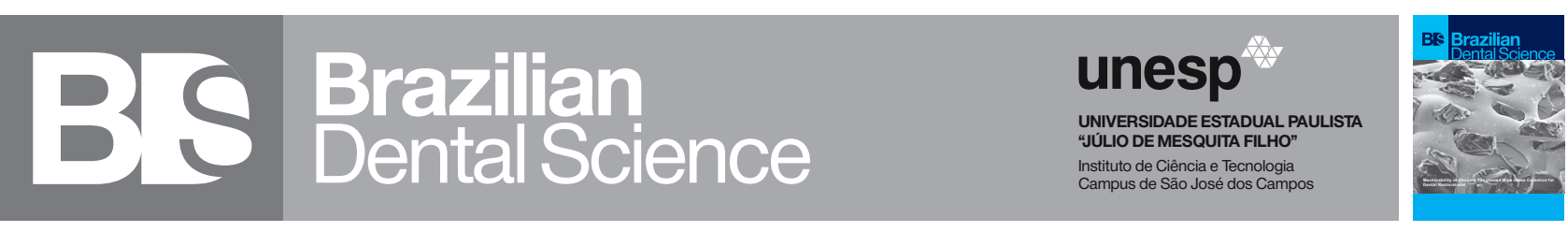

\title{
Effect of the polishing procedure and surface sealant application on fluoride release
}

\author{
Efeito do procedimento de polimento e aplicação superficial de selante na liberação de flúor \\ Muhittin UGURLU ${ }^{1}$ \\ 1 - Department of Restorative Dentistry, Faculty of Dentistry, Süleyman Demirel University, Turkey.
}

\begin{abstract}
Objectives: This study aimed to assess the effect of the polishing procedure and surface sealant application on the fluoride release of restorative materials. Material and Methods: The groups were consisted of using five different restorative materials were employed: Beautifil II, GCP Glass Fill, Amalgomer CR, Zirconomer and Fuji IX GP. 30 disk-shaped specimens $(8 \times 2 \mathrm{~mm})$ were prepared from each material. Each group was subdivided into three groups considering finishing procedures: Mylar strip, polishing with Super-Snap discs, G-Coat Plus application after polishing with Super-Snap discs. The amount of fluoride released into distilled water was measured using a fluoride ion-selective electrode and ion analyzer after 24 hours, followed by measurement on days $3,7,15,21$, and 28 . Surface analysis of the materials was performed with SEM (Scanning Electron Microscopy) and EDS (Energy Dispersive X-ray Spectroscopy). The data were statistically analyzed using two-way repeated measure ANOVA and LSD test $(\mathrm{p}=0.05)$. Results: The highest amount of fluoride released was measured after the first $24 \mathrm{~h}$ for all materials. Beautifil II released less fluoride than other materials in all measurement periods $(\mathrm{p}<0.05)$. After polishing, the amount of fluoride released from all materials except Beautifil II increased $(p<0.05)$. The application of G-Coat Plus did not impact the amount of fluoride release of any materials ( $p>0.05)$. EDS analysis showed the most percentage of oxygen in all materials. Conclusion: The polishing procedure might induce an increase in fluoride release of glass ionomerbased materials, and the application of G-Coat Plus cannot affect the amount of fluoride release.
\end{abstract}

\section{KEYWORDS}

Energy dispersive x-ray spectroscopy; Fluoride; Glass ionomer cement.

\section{RESUMO}

Objetivos: Este estudo teve como objetivo avaliar o efeito do procedimento de polimento e aplicação de selante superficial na liberação de flúor de materiais restauradores. Material e Métodos: Os grupos consistiram na utilização de cinco materiais restauradores diferentes: Beautifil II, GCP Glass Fill, Amalgomer CR, Zirconomer e Fuji IX GP. Trinta espécimes em forma de disco $(8 \times 2 \mathrm{~mm})$ foram preparados a partir de cada material. Cada grupo foi subdividido em três grupos considerando os procedimentos de acabamento: tira Mylar, polimento com discos Super-Snap, aplicação de G-Coat Plus após polimento com discos Super-Snap. A quantidade de flúor liberada na água destilada foi medida usando um eletrodo íon-seletivo de fluoreto e analisador de íons após 24 horas, seguido pela medição nos dias 3, $7,15,21$ e 28. A análise da superfície dos materiais foi realizada com MEV (Microscopia Eletrônica de Varredura) e EDS (Espectroscopia de Energia Dispersiva de Raios-X). Os dados foram analisados estatisticamente usando ANOVA de dois fatores com medidas repetidas e teste LSD ( $\mathrm{p}=$ 0,05). Resultados: A maior quantidade de flúor liberado foi medida após as primeiras 24 horas para todos os materiais. O Beautifil II liberou menos flúor do que outros materiais em todos os períodos avaliados ( $\mathrm{p}<0,05)$. Após o polimento, a quantidade de flúor liberada de todos os materiais, exceto Beautifil II, aumentou ( $p<0,05)$. A aplicação de G-Coat Plus não afetou a quantidade de liberação de flúor de nenhum material ( $p>0,05)$. A análise por EDS revelou a maior porcentagem de oxigênio em todos os materiais. Conclusão: O procedimento de polimento pode induzir um aumento na liberação de flúor de materiais à base de ionômero de vidro, e a aplicação de G-Coat Plus não pode afetar a quantidade de liberação de flúor.

\section{PALAVRAS-CHAVE}

Espectroscopia de energia dispersiva de raios-X; Fluoreto; Cimento de ionômero de vidro. 


\section{INTRODUCTION}

lass ionomer cements (GICs) have widely $\tau$ been used for a long time in dentistry due to their beneficial properties, including biological compatibility, chemical adhesion, and especially fluoride-releasing which contribute to caries preventive character [1,2]. Seconder caries are the most widespread cause of the failure of restorations [3]. Fluoride is an essential factor in the prevention and treatment of dental caries through the reduction of the mineral dental structure solubility and inhibition of microbial metabolism [1,3]. Previous studies have stated that the use of fluoride-releasing restorative materials decreased the incidence of recurrent caries $[1,2]$. The measurement of the amount of fluoride released into distilled water within a determined period by laboratory studies is a used method to determine the cariostatic properties of restorative materials [4].

The GIC has certain disadvantages, such as early water sensitivity and low mechanical strengths; therefore, the clinical use of GICs is limited [2,5]. Several glass-ionomer based materials have been developed to improve low mechanical properties [2]. Some of these materials are giomer, glass carbomer, ceramic reinforced GIC, zirconia reinforced GIC and high viscosity GIC. Giomer is a hybridization material of GIC and composite resin, involving surface pre-reacted glass ionomer [S-PRG] filler particles within a resin matrix [6,7]. Glass carbomer has calcium fluorapatite nanocrystals [6]. The reinforced GICs contain different metal particles in the filler component [6]. The powder/liquid ratio of high viscosity GIC is higher than the conventional GIC [8]. The application of surface coating agents is also recommended to improve the mechanical properties of the glass ionomerbased materials by hindering early water contamination [9].

Moreover, the smooth surfaces of restorative materials are an important factor to increase the success of the restorations and prevent discoloration [10]. Polishing procedures make the surface smoother and remove surface damages created during the finishing step $[6,10]$. Previous studies have evaluated the effect of various polishing systems on surface roughness $[2,6,10,11]$. It has been reported that none of the various polishing systems might reproduce the surface smoothness created by a Mylar strip [10]. However, the correct anatomical form of the restoration may not be achieved by using only a Mylar strip [10]. The fluoride release of materials may differ according to the material type and different factors [7]. Previous studies have evaluated the effect of polishing on the fluoride release of restorative materials, but this effect is not clear $[2,6,12,13]$. The effect of surface coating agents on fluoride release is also not clear.

Therefore, the purpose of this study was to compare the amount of fluoride released of different restorative materials and evaluate the effect of the polishing procedure and surface sealant application on the fluoride release of materials. The tested null hypotheses are (1) that the amounts of fluoride release of restorative materials would be no different (2) that the polishing procedure and surface sealant application would not affect the fluoride release of materials.

\section{MATERIAL AND METHODS}

\section{Specimen preparation}

The tested restorative materials were a giomer (Beautifil II; Shofu, Kyoto, Japan), a glass carbomer (GCP Glass Fill; GCP, Vianen, Netherlands), a ceramic reinforced GIC (Amalgomer CR; Advanced Health Care, Kent, UK), a zirconia reinforced GIC (Zirconomer; Shofu, Kyoto, Japan) and a high viscosity GIC (Fuji IX GP Capsule; GC, Tokyo, Japan), (Table I). 30 disk-shaped specimens ( $8 \mathrm{~mm}$ in diameter and $2 \mathrm{~mm}$ thickness) were prepared from each 
material for the measurement of the amount of fluoride released. For SEM and EDS analyses, 3 disk-shaped specimens ( $4 \times 1 \mathrm{~mm})$ were prepared from each material (Figure 1). Each material was placed into a Teflon mold and pressed on both sides with Mylar strips and glass plates. The giomer material was polymerized through the glass plate using a LED light-curing unit (Smartlite Focus; Dentsply, Milford, DE, USA, $1000 \mathrm{~mW} / \mathrm{cm}^{2}$ ) according to the manufacturer's instructions. A capsule mixer (Silver Mix; Stomamed, Bratislava, Slovakia) was employed for 10 seconds of mixing before the application of the glass carbomer and the high viscosity GIC. The ceramic reinforced GIC and the zirconia reinforced GIC were hand-mixed within a total of 30 seconds according to the manufacturer's instructions. After the light-curing and setting cycle, the specimens were removed from the mold.

Table I - Data collection. The blind reverse torque values of all short and standard implants had been measured with digital torque meter

\begin{tabular}{|c|c|c|c|c|}
\hline Materials & Type & Composition & Manufacturer & Lot \\
\hline Beautifil II & Giomer & $\begin{array}{l}\text { BISGMA, TEGDMA, inorganic } \\
\text { glass filler, aluminium oxide, silica, } \\
\text { prereacted glass ionomer filler, } \\
\text { Camphoroquinone }\end{array}$ & $\begin{array}{l}\text { Shofu, Kyoto, } \\
\text { Japan }\end{array}$ & 111787 \\
\hline $\begin{array}{l}\text { GCP Glass } \\
\text { Fill }\end{array}$ & $\begin{array}{l}\text { Glass } \\
\text { carbomer }\end{array}$ & $\begin{array}{l}\text { Fluoroaluminosilicate glass, nano } \\
\text { fluoro/hydroxyapatite, polyacids }\end{array}$ & $\begin{array}{l}\text { GCP, Vianen, } \\
\text { Netherlands }\end{array}$ & 71702144 \\
\hline $\begin{array}{l}\text { Amalgomer } \\
\text { CR }\end{array}$ & $\begin{array}{l}\text { Ceramic } \\
\text { reinforced } \\
\text { GIC }\end{array}$ & $\begin{array}{l}\text { Powder:Fluoroaluminosilicate } \\
\text { glass, polyacrylic acid powder, } \\
\text { tartaric acid powder, ceramic } \\
\text { reinforcing powder. } \\
\text { Liquid:Polyacrylic acid, distilled } \\
\text { water }\end{array}$ & $\begin{array}{l}\text { Advanced Health } \\
\text { Care, Kent, UK }\end{array}$ & 011804-81 \\
\hline Zirconomer & $\begin{array}{l}\text { Zirconia } \\
\text { reinforced } \\
\text { GIC }\end{array}$ & $\begin{array}{l}\text { Powder:Fluoroaluminosilicate } \\
\text { glass, zirconium oxide, pigments } \\
\text { Liquid: Polyacrylic acid solution, } \\
\text { tartaric acid }\end{array}$ & $\begin{array}{l}\text { Shofu, Kyoto, } \\
\text { Japan }\end{array}$ & 02160281 \\
\hline Fuj। IX GP & $\begin{array}{l}\text { High } \\
\text { viscosity } \\
\text { GIC }\end{array}$ & $\begin{array}{l}\text { Polyacrylic acid, fluoroaluminosi- } \\
\text { licate glass, polybasic carboxylic } \\
\text { acid }\end{array}$ & GC, Tokyo, Japan & $180110 \mathrm{~A}$ \\
\hline
\end{tabular}

Bis-GMA: Bisphenol A diglycidyl methacrylate; TEGDMA: Triethylene glycole dimethacrylate.

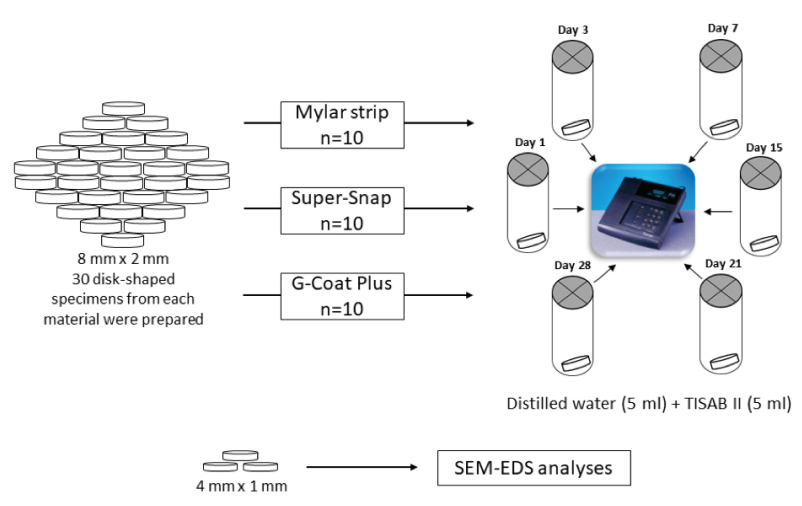

Figure 1 - Schematic illustrating the study design and methodology.

\section{Fluoride release measurement}

The specimens were randomly divided into three subgroups for each material after storage for 1 hour at $37^{\circ} \mathrm{C}$ and $100 \%$ humidity $(n=10)$. Mylar strip (Control), Super-Snap, and G-Coat Plus. The control group received no polishing after preparation with Mylar strip (Table II). In Super-Snap subgroup, the specimens were polished with a multi-step polishing system (Super Snap Rainbow Technique Kit, Shofu, Kyoto, Japan, Lot:0413007). The polishing was performed on the two surfaces of the disk-shaped specimens. During polishing, each abrasive disk was used only once for each material, in the wet condition for 1 minute, using handpiece rotating 10.000 revolutions per minute recommended by the manufacturer. After each polishing step, all the specimens were thoroughly rinsed with water and air-dried. In G-Coat Plus subgroup, the specimens were polished with the same procedure as mentioned above. After polishing, G-Coat Plus (GC, Tokyo, Japan, Lot:1710031) was applied using a micro-tip applicator to the polished surfaces and light-cured for 20 seconds with a LED light-curing unit (Smartlite Focus) according to manufacturer's instructions. 
Table II - The experimental subgroups with surface treatments

\begin{tabular}{|c|c|}
\hline Subgroups & Surface treatments \\
\hline Mylar strip (Control) & $\begin{array}{l}\text { The surfaces were received no polishing after preparation with } \\
\text { Mylar strip }\end{array}$ \\
\hline Super-Snap & $\begin{array}{l}\text { The two surfaces of the disk-shaped specimens were polished with } \\
\text { Super-Snap discs. }\end{array}$ \\
\hline G-CoatPlus & $\begin{array}{l}\text { The two surfaces of the disk-shaped specimens were polished with } \\
\text { Super-Snap discs. Following polishing, G-Coat Plus was applied to } \\
\text { the polished surfaces. }\end{array}$ \\
\hline
\end{tabular}

Each specimen was immersed in a plastic container containing $5 \mathrm{~mL}$ of distilled water at $37^{\circ} \mathrm{C}$. After $24 \mathrm{~h}$, the containers were thoroughly shaken, and the water was removed. After rinsing with distilled water, the specimens were re-immersed in $5 \mathrm{~mL}$ of fresh distilled water. Measurements of fluoride released were evaluated after 24 hours followed by measurement on days $3,7,15,21$, and 28 . Each $5 \mathrm{~mL}$ storage water was mixed with $5 \mathrm{~mL}$ of total ionic strength adjustable buffer (TISAB II) solution and analyzed using a fluoride ion-specific electrode (Orion 9609BNWP, Orion Research, Chicago, IL, USA) and an ion analyzer (Thermo Orion $720 \mathrm{~A}+$, Orion Research, Chicago, IL, USA). The system was calibrated before each evaluation with fluoride standards ranging from 0.1 to $100 \mathrm{ppm}$. The amount of fluoride released was calculated in ppm for each test period.

\section{SEM and EDS analysis}

After storage for 24 hours at $37^{\circ} \mathrm{C}$ and $100 \%$ humidity, the specimens were gently polished using with a multi-step polishing system (Super Snap Rainbow Technique Kit). The specimens were ultrasonically cleaned for five minutes in distilled water. The samples were inserted in an aluminum sample holder and fixed with carbon tape and viewed with a scanning electron microscope (SEM, Quanta Feg 250, FEI, Eindhoven, Netherlands). EDS analysis was performed at the same time as SEM analysis. An area of approximately $50 \times 40$ $\mu \mathrm{m}$ from the center of each specimen was selected for EDS analysis. The mean and standard deviation of weight percentages of the main constituents in the materials were calculated.

\section{Statistical analysis}

Statistical analysis was done with the SPSS Program, version 20.0 (Statistical Package for the Social Sciences; SPSS, Chicago, IL, USA). The data were analyzed using two-way repeated measure analysis of variance (ANOVA). A least significant difference (LSD) post-hoc test was used for multiple comparisons. The p-value of less than 0.05 was considered statistically significant for all statistical analyses.

\section{RESULTS}

The amounts of fluoride released from the materials on all test periods are presented in Table III and graphically illustrated in Figures 2 and 3. In each subgroup of all materials, the amount of fluoride released was the highest after $24 \mathrm{~h}$. The amount of fluoride released reduced over time but sustained along the entire 28day test period. After $24 \mathrm{~h}$, the lowest amount of fluoride released was found in Beautifil II $(p<0.05)$. During all measurement days, the amounts of fluoride released of all materials except Beautifil II increased after polishing $(\mathrm{p}<0.05)$. The polishing procedure decreased fluoride release of Beautifil II on the 1st, 3rd and 7 th days $(\mathrm{p}<0.05)$, but it did not impact on the 15th, 21st, and 28th days ( $\mathrm{p}>0.05$ ). The G-Coat Plus application did not influence fluoride release of any materials on all test periods ( $\mathrm{p}>0.05)$. After $24 \mathrm{~h}$, the greatest amount of fluoride was released from GCP Glass Fill in Super-Snap and G-Coat Plus subgroups $(\mathrm{p}<0.05)$.

The chemical composition of the materials detected by EDS analysis is presented in Table IV. Some representative SEM photomicrographs are shown in Figure 4. A dominant portion of oxygen was found in all materials. Zirconium was observed in Zirconomer, Amalgomer CR, and GCP Glass Fill. Potassium was found in all materials except Zirconomer. Strontium was determined in Fuj1 IX GP, Beautifil II, and GCP Glass Fill. Phosphate was observed in only GCP Glass Fill. 
Table III - Mean and standard deviation values of the amounts of fluoride release (ppm) for each material and subgroup during the test periods

\begin{tabular}{|c|c|c|c|c|c|c|c|}
\hline & & Beautifil II & GCP Glass Fill & Amalgomer CR & Zirconomer & Fujı IX GP & $p^{\star *}$ \\
\hline \multirow{4}{*}{ Day 1} & Mylar strip & $2.17 \pm 0.43^{\mathrm{aA}}$ & $12.10 \pm 2.07^{\mathrm{aB}}$ & $11.83 \pm 2.02^{\mathrm{aB}}$ & $11.92 \pm 2.00^{\mathrm{aB}}$ & $7.86 \pm 1.12^{\mathrm{ac}}$ & 0.000 \\
\hline & Super-Snap & $1.78 \pm 0.38^{\mathrm{bA}}$ & $29.11 \pm 2.31^{\mathrm{BB}}$ & $18.96 \pm 1.82^{\mathrm{bC}}$ & $21.60 \pm 2.33^{\mathrm{bD}}$ & $15.74 \pm 1.42^{\mathrm{bE}}$ & 0.000 \\
\hline & G-Coat Plus & $1.79 \pm 0.40^{\mathrm{bA}}$ & $29.15 \pm 2.32^{\text {ВВ }}$ & $19.05 \pm 1.98^{b c}$ & $21.93 \pm 2.75^{\mathrm{bD}}$ & $15.95 \pm 1.36^{\mathrm{bE}}$ & 0.000 \\
\hline & $p^{*}$ & 0.002 & 0.000 & 0.000 & 0.000 & 0.000 & \\
\hline \multirow{4}{*}{ Day 3} & Mylar strip & $1.40 \pm 0.38^{a A}$ & $3.52 \pm 1.48^{a B}$ & $3.43 \pm 1.55^{1 \mathrm{~B}}$ & $3.70 \pm 0.72^{\mathrm{aB}}$ & $1.80 \pm 0.36^{\mathrm{aA}}$ & 0.000 \\
\hline & Super-Snap & $1.00 \pm 0.30^{\mathrm{bA}}$ & $14.75 \pm 1.19^{\mathrm{bB}}$ & $5.54 \pm 0.87^{\circ \mathrm{CC}}$ & $7.87 \pm 0.94^{\mathrm{bD}}$ & $4.35 \pm 0.80^{\mathrm{bE}}$ & 0.000 \\
\hline & G-CoatPlus & $1.00 \pm 0.30^{\mathrm{bA}}$ & $14.65 \pm 1.06^{\mathrm{bB}}$ & $5.64 \pm 0.99^{\mathrm{bc}}$ & $7.91 \pm 0.95^{\mathrm{bD}}$ & $4.65 \pm 0.91^{\mathrm{be}}$ & 0.000 \\
\hline & $\mathrm{p}^{*}$ & 0.013 & 0.000 & 0.000 & 0.000 & 0.000 & \\
\hline \multirow{4}{*}{ Day 7} & Mylar strip & $0.88 \pm 0.08^{\mathrm{aA}}$ & $1.33 \pm 0.37^{\mathrm{aB}}$ & $0.96 \pm 0.34^{\mathrm{AAB}}$ & $2.41 \pm 0.78^{a c}$ & $0.89 \pm 0.15^{\mathrm{aA}}$ & 0.000 \\
\hline & Super-Snap & $0.77 \pm 0.12^{\mathrm{bA}}$ & $8.01 \pm 1.02^{\mathrm{bB}}$ & $3.34 \pm 0.59^{\mathrm{bc}}$ & $4.39 \pm 0.83^{\mathrm{bD}}$ & $2.43 \pm 0.44^{\mathrm{bE}}$ & 0.000 \\
\hline & G-CoatPlus & $0.79 \pm 0.10^{\mathrm{bA}}$ & $7.92 \pm 0.95^{\mathrm{bB}}$ & $3.35 \pm 0.58^{\mathrm{bc}}$ & $4.43 \pm 0.83^{\mathrm{bD}}$ & $2.52 \pm 0.42^{\mathrm{bE}}$ & 0.000 \\
\hline & $p^{*}$ & 0.039 & 0.000 & 0.000 & 0.000 & 0.000 & \\
\hline \multirow{4}{*}{ Day 15} & Mylar strip & $0.60 \pm 0.09^{\mathrm{aA}}$ & $1.00 \pm 0.36^{a \mathrm{~B}}$ & $0.80 \pm 0.10^{\mathrm{aAB}}$ & $1.96 \pm 0.45^{a c}$ & $0.78 \pm 0.08^{\mathrm{aAB}}$ & 0.000 \\
\hline & Super-Snap & $0.56 \pm 0.16^{\mathrm{aA}}$ & $6.94 \pm 0.49^{\text {вВ }}$ & $1.94 \pm 0.12^{\mathrm{bc}}$ & $2.94 \pm 0.73^{\mathrm{bD}}$ & $1.60 \pm 0.45^{\mathrm{bc}}$ & 0.000 \\
\hline & G-Coat Plus & $0.52 \pm 0.22^{1 \mathrm{~A}}$ & $6.88 \pm 0.43^{\mathrm{bB}}$ & $1.96 \pm 0.11^{\mathrm{bc}}$ & $2.93 \pm 0.73^{\mathrm{bD}}$ & $1.64 \pm 0.44^{\mathrm{bC}}$ & 0.000 \\
\hline & $\mathrm{p}^{*}$ & 0.579 & 0.000 & 0.000 & 0.002 & 0.000 & \\
\hline \multirow{4}{*}{ Day 21} & Mylar strip & $0.38 \pm 0.11^{12 A}$ & $0.87 \pm 0.29^{\mathrm{aB}}$ & $0.71 \pm 0.09^{a c}$ & $0.96 \pm 0.18^{\mathrm{aB}}$ & $0.69 \pm 0.07^{\mathrm{ac}}$ & 0.000 \\
\hline & Super-Snap & $0.32 \pm 0.12^{2 \mathrm{~A}}$ & $5.69 \pm 0.74^{\mathrm{bB}}$ & $1.62 \pm 0.35^{\mathrm{bc}}$ & $2.08 \pm 0.28^{\mathrm{bD}}$ & $1.56 \pm 0.40^{\mathrm{bc}}$ & 0.000 \\
\hline & G-Coat Plus & $0.31 \pm 0.14^{\mathrm{aA}}$ & $5.62 \pm 0.67^{\mathrm{bB}}$ & $1.65 \pm 0.36^{\mathrm{bc}}$ & $2.09 \pm 0.29^{\mathrm{bD}}$ & $1.57 \pm 0.40^{\mathrm{bc}}$ & 0.000 \\
\hline & $\mathrm{p}^{*}$ & 0.390 & 0.000 & 0.000 & 0.000 & 0.000 & \\
\hline \multirow{4}{*}{ Day 28} & Mylar strip & $0.17 \pm 0.09^{a A}$ & $0.75 \pm 0.22^{1 \mathrm{aB}}$ & $0.63 \pm 0.08^{\mathrm{ac}}$ & $0.83 \pm 0.09^{\mathrm{aB}}$ & $0.62 \pm 0.10^{\mathrm{ac}}$ & 0.000 \\
\hline & Super-Snap & $0.14 \pm 0.07^{\mathrm{aA}}$ & $4.86 \pm 0.78^{\circ B}$ & $1.46 \pm 0.32^{\mathrm{bc}}$ & $1.93 \pm 0.44^{\mathrm{bD}}$ & $1.50 \pm 0.33^{\mathrm{bc}}$ & 0.000 \\
\hline & G-Coat Plus & $0.13 \pm 0.07^{\mathrm{aA}}$ & $4.93 \pm 0.75^{\mathrm{BB}}$ & $1.47 \pm 0.33^{\mathrm{pc} c}$ & $1.93 \pm 0.45^{\mathrm{bD}}$ & $1.49 \pm 0.35^{b c}$ & 0.000 \\
\hline & $\mathrm{p}^{*}$ & 0.468 & 0.000 & 0.000 & 0.000 & 0.000 & \\
\hline
\end{tabular}

Same small/capital letter indicates no statistical difference in the column and row, respectively for each measurement day. $\mathrm{p}^{*}$ : Significance level between subgroups for each material on the test day.

$\mathrm{p}^{\star *}$ : Significance levels of among the materials in each subgroup at the test day.

Table IV - Weight percentages of the main constituents of the materials' surfaces identified with EDS

\begin{tabular}{|c|c|c|c|c|c|}
\hline & Beautifil II & GCP Glass Fill & Amalgomer CR & Zirconomer & FujıIX GP \\
\hline C & $25.07 \pm 0.98$ & $10.72 \pm 0.67$ & Notidentified & $12.32 \pm 0.99$ & $12.41 \pm 0.86$ \\
\hline 0 & $35.66 \pm 1.05$ & $40.04 \pm 2.01$ & $42.26 \pm 2.13$ & $35.45 \pm 1.56$ & $32.70 \pm 1.03$ \\
\hline $\mathbf{F}$ & $5.01 \pm 0.58$ & $6.48 \pm 0.75$ & $8.31 \pm 0.82$ & $9.23 \pm 0.87$ & $9.32 \pm 0.20$ \\
\hline $\mathrm{Na}$ & $2.01 \pm 0.01$ & $1.74 \pm 0.01$ & $5.04 \pm 0.65$ & $5.84 \pm 0.35$ & $1.39 \pm 0.03$ \\
\hline Al & $9.46 \pm 0.92$ & $11.31 \pm 0.25$ & $14.46 \pm 0.99$ & $13.33 \pm 0.89$ & $13.37 \pm 0.92$ \\
\hline $\mathrm{Si}$ & $8.45 \pm 0.72$ & $12.18 \pm 0.33$ & $19.80 \pm 1.09$ & $15.22 \pm 0.99$ & $14.82 \pm 0.85$ \\
\hline $\mathrm{Zr}$ & Notidentified & $0.46 \pm 0.02$ & $3.68 \pm 0.13$ & $4.10 \pm 0.05$ & Not identified \\
\hline K & $0.14 \pm 0.01$ & $0.14 \pm 0.01$ & $0.37 \pm 0.01$ & Notidentified & $0.16 \pm 0.01$ \\
\hline $\mathrm{Ca}$ & $0.18 \pm 0.03$ & $3.71 \pm 0.03$ & $6.08 \pm 0.75$ & $4.51 \pm 0.08$ & $0.13 \pm 0.01$ \\
\hline $\mathrm{Sr}$ & $14.02 \pm 0.88$ & $9.90 \pm 0.54$ & Not identified & Notidentified & $15.70 \pm 0.65$ \\
\hline $\mathbf{P}$ & Notidentified & $3.33 \pm 0.06$ & Not identified & Notidentified & Not identified \\
\hline
\end{tabular}




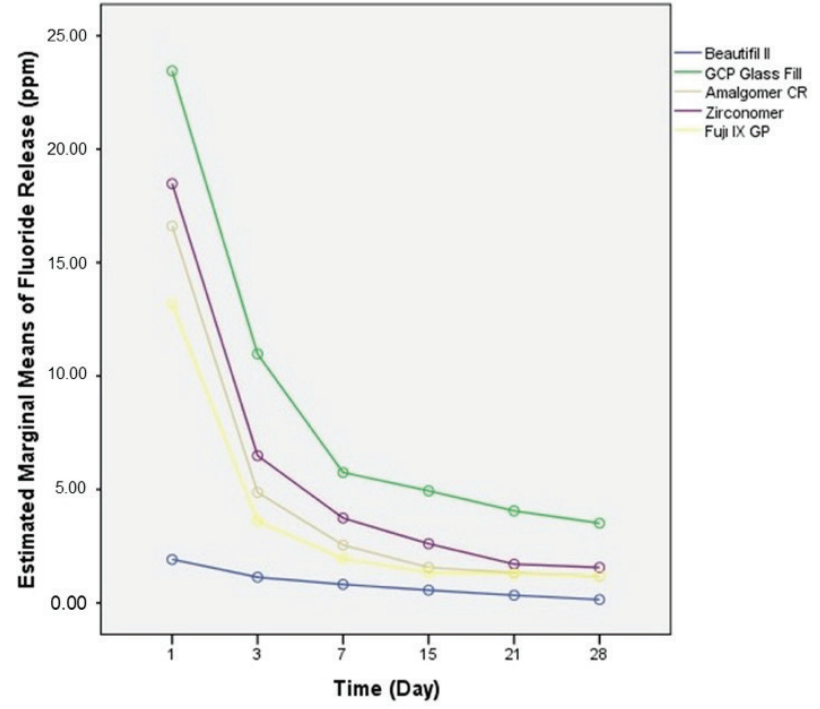

Figure 2 - Relationship between the fluoride release of materials and the time.

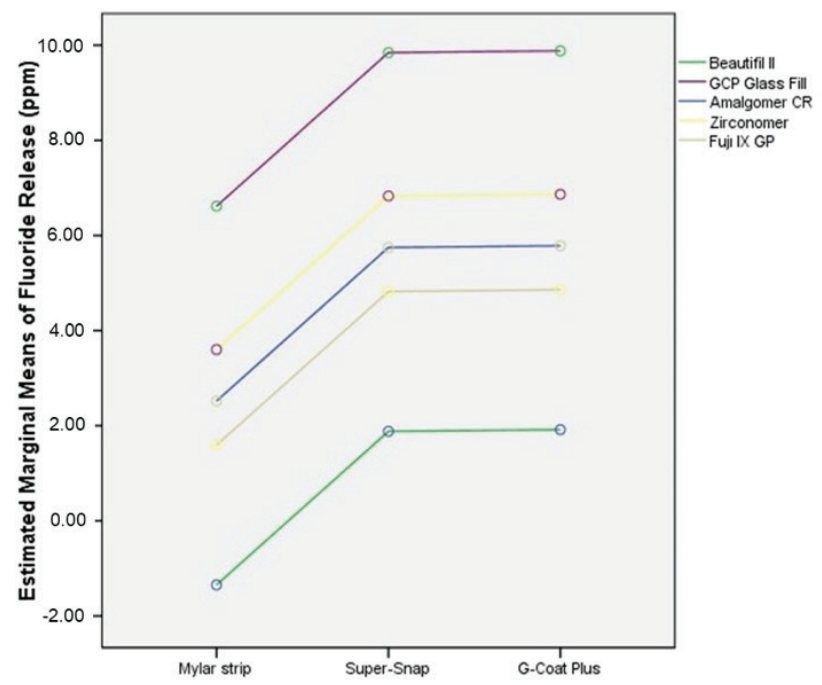

Figure 3 - Relationship between the fluoride release of materials and the finishing procedures.

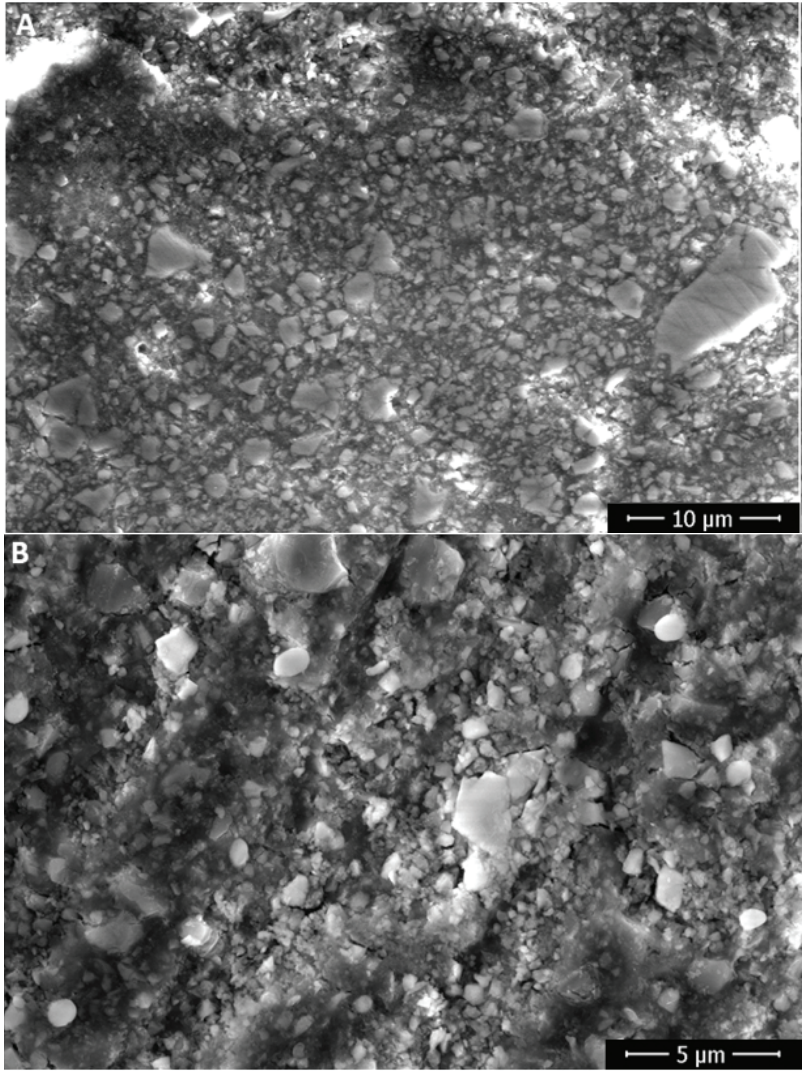

Figure 4 - SEM photomicrographs of the materials' surface (A: Beautifil II, B: GCP Glass Fill). The photomicrographs were obtained with secondary electrons mode at $15 \mathrm{kV}$. The particle shapes of the materials, the observed cracks on the surface of GCP Glass Fill.

\section{DISCUSSION}

In contemporary dental practice, the use of fluoride-releasing restorative materials has gradually increased due to especially the caries preventive effect of fluoride [1,2]. The amount of fluoride release from restorative materials have been evaluated by several laboratory studies $[4,6-8,14]$. The amounts of fluoride release of restorative materials show an alteration based on different factors, including the type of material, the chemical composition of material, the powder-liquid ratio during mixing, mixing method, storage medium, $\mathrm{pH}$ of the environment, and finishing/polishing procedures $[7,14]$.

The fluoride release from glass-ionomer based materials occurs via two mechanisms $[15,16]$. The first one is a short-term reaction 
at which the highest amount of fluoride releases [16]. The content of GIC is a fluoroaluminosilicate glass powder and an aqueous solution of polyacrylic acid [1]. An acid-base reaction takes place between the fluoroaluminosilicate glass and the polyacrylic acid with mixing the powder and the liquid [1]. The high fluoride release following the first 24 hours is because of the reaction of the polyacrylic acid with the fluoride-containing glass particles during the setting reaction [16]. The second mechanism is more gradual and slower. The slower fluoride release during the following days has been attributed to the diffusion of fluoride ions, which form by slower dissolution of glass particles $[1,16]$. The diffusion of fluoride ions occurs through pores and cracks on the material surface [15].

In the present study, Beautifil II released quite a lower amount of fluoride than the glassionomer based materials during all of the test periods. This result is in agreement with previous studies, which concluded that the fluoride release capability of giomer material was lower than the glass-ionomer based materials $[6,7,17,18]$. The lower fluoride release of Beautifil II results from including only S-PRG particles as a fluoride component, without a glass ionomer matrix $[6,17]$. The tested other materials in this study have an acid-base setting reaction. Beautifil II includes no glass ionomer matrix phase, since the absence of an acid-base reaction [2,17]. It contains S-PRG particles which are produced by the acid-base reaction between the surface of fluoridated glass fillers and the poly-acrylic acid [17]. Moreover, it has been reported that the resin in the resin-based materials might act as a diffusion barrier for fluoride ions. The resin content of Beautifil II may also be responsible for low fluoride release [17].

It is well known that GICs show the highest amount of fluoride release on the first day, and then the fluoride release quickly reduces and stabilizes the following three to four weeks
$[1,6,19,20]$. This phenomenon is termed burst effect, in which the rapid elution of the fluoride ions as a result of the acid-base reaction $[6,19]$. GCP Glass Fill, Amalgomer CR, Zirconomer, and Fuji IX GP released the highest amount of fluoride after $24 \mathrm{~h}$ based on the burst effect, as in previous studies $[6,15,18,20]$. The highest amount of fluoride release was observed from GCP Glass Fill after polishing during all of the test periods. Amalgomer CR and Zirconomer released more fluoride than Fuj1 IX GP. The difference in the amounts of fluoride released might be due to that the chemical composition of the materials is different $[8,15,20,21]$. Therefore, the first null hypothesis that the amounts of fluoride release of restorative materials would be no different was rejected.

Previous studies have concluded that the polishing procedures increased the amount of fluoride released based on the type of material $[6,12,13]$. It has been stated that the removal of superficial cement layers of GICs with polishing increased the fluoride released by allowing a higher amount of fluoride release from deeper layers $[12,13]$. In the present study, the amount of fluoride released from GCP Glass Fill, Amalgomer CR, Zirconomer, and Fuji IX GP increased after the polishing procedure. The polishing procedure could also be increased the amount of fluoride released by way of increasing the surface roughness of materials [22]. However, the polishing procedure decreased the fluoride release of Beautifil II at the 1st, 3rd and 7th days, but it was not effective at later measurement periods. It has been reported that the polishing was ineffective in the increase of fluoride release of Beautifil II. It has been attributed to the existence of a surface modification layer that preserves the glass core [6]. This layer might prevent the increase in fluoride release of giomer materials after polishing procedures [6]. Furthermore, the polishing procedure may remove the surface layer of giomer, which may release more fluoride. 
The surface porosity and roughness of glass ionomer-based materials have an important effect on the amount of fluoride release $[16,17]$. It has been reported that the surface roughness of materials was the lowest if Mylar strips were used during specimen preparation, but the surface roughness increased after polishing procedures $[4,6,10]$. Previous studies have concluded that the application of G-Coat Plus decreased the amount of fluoride released from glass ionomer-based materials [21,23,24]. The authors have stated that surface coating with G-Coat Plus occluded pores on the surface of the material, prevented the superficial rinse mechanism of water, and reduced the movement of fluoride ions, thus; decreasing the fluoride released. Nevertheless, it has also been reported that the application G-Coat Plus did not affect the surface roughness of GICs [11]. In this study, the application of G-Coat Plus did not influence the fluoride release of glass-ionomer based materials. Therefore, the second null hypothesis that the polishing procedure and surface sealant application would not affect the fluoride release of materials was partially rejected. This inefficacy of G-Coat Plus could be due to the intensifier effect of the polishing procedure on the fluoride release. The application of G-Coat Plus without polishing procedure could hinder the fluoride release because the amount of fluoride released from the specimens prepared without polishing procedure was less, but the specimens with polishing released more fluoride.

EDS analysis is a confidently used method to identify and quantify major components on the material's surface, though it has some disadvantages [8,25]. In this study, EDS analysis showed the differences in the chemical compositions of the materials' surface. It has been stated that the amount of fluoride released of materials might be related to their fluoride content [1]. Nonetheless, although GCP Glass Fill had a lower percentage of fluoride than Amalgomer CR, Zirconomer, and Fujı IX GP, it released more fluoride after polishing procedure. The EDS analysis cannot exactly determine the chemical compositions of materials because it is performed on the material's surface, and the analysis depth being approximately $1 \mu \mathrm{m}[8,25]$. The fluoride release' resource of GCP Glass Fill may be a deeper layer of the material.

In laboratory studies, the various mediums may be preferred in the assessment of the fluoride release of dental materials, such as distilled water, artificial saliva, and $\mathrm{pH}$-cycling models [26]. Although the artificial saliva and pH-cycling models may better simulate the oral environment, the distilled water is an easily procurable medium which shows well the fluoride release of the materials [3]. It has also been stated that the amount of fluoride released from the materials was higher when they were stored in distilled water compared to storage in artificial saliva, but the patterns of fluoride release was similar [5]. Wherefore, distilled water was used as a specimen storage solution in this study. The different storage media, except distilled water, may alter the in vitro results. The in vitro researches cannot reflect the physical conditions of fluoride release of restorative materials in the oral cavity because the conditions of the oral environment are quite different. Long-term in vitro studies are also needed to determine the fluoride release characteristic of the materials. Furthermore, the relationship between the fluoride release of materials and caries preventive effect must be investigated by laboratory and clinical trials.

\section{CONCLUSIONS}

Within the limitations of this in vitro study, it may be concluded that giomer released a lower amount of fluoride than other glass ionomerbased materials. The polishing procedure might increase the amount of fluoride release of glass-ionomer based material. The application of G-Coat Plus after polishing might not affect fluoride release. 


\section{Acknowledgements}

The authors would like to thank Shofu Dental, GC Corporation, Dual Dental and Advanced Healthcare Ltd, for the material support of this study. The used materials and method in this study was similar to a previous study mentioned below.

Ugurlu M, Ozkan EE, Ozseven A. The effect of ionizing radiation on properties of fluoride-releasing restorative materials. Braz Oral Res. 2020;34:e005. doi:10.1590/18073107bor-2020.vol34.0005

\section{Source(s) of support}

The material support was provided by Shofu Dental, GC Corporation, Dual Dental and Advanced Healthcare Ltd.

\section{Conflicting Interest (If present, give more details)}

No conflict of interest

\section{REFERENCES}

1. Wiegand A, Buchalla W, Attin T. Review on fluoride-releasing restorative materials--fluoride release and uptake characteristics, antibacterial activity and influence on caries formation. Dent Mater. 2007;23(3):343-62 doi:10.1016/.j.dental.2006.01.022

2. Garoushi S, VallittuPK, Lassila L. Characterization of fluoride releasing restorative dental materials. Dent Mater J. 2018;37(2):293-300. doi:10.4012/ dmj.2017-161

3. Cury JA, de Oliveira BH, dos Santos AP, Tenuta LM. Are fluoride releasing dental materials clinically effective on caries control?. Dent Mater.2016;32(3):323-33. doi:10.1016/j.dental.2015.12.002

4. Cabral MF,Martinho RL, Guedes-Neto MV, Rebelo MA, Pontes DG, CohenCarneiro F.Do conventional glass ionomer cements release more fluoride than resin-modified glass ionomer cements? Restor DentEndod. 2015:40(3):209_ 15. doi:10.5395/rde.2015.40.3.209

5. Shiozawa M, Takahashi $H$, Iwasaki N. Fluoride release and mechanical properties after 1-year water storage of recent restorative glass ionomer cements. Clin Oral Investig. 2014;18(4):1053-60. doi:10.1007/s00784-013-1074-

6. Bayrak GD, Sandalli N, Selvi-Kuvvetli S, Topcuoglu N, Kulekci G. Effect of two different polishing systems on fluoride release, surface roughness and bacterial adhesion of newly developed restorative materials. J Esthet Restor Dent. 2017:29(6):424-34. doi:10.1111/jerd.12313

7. Jingarwar MM, Pathak A, BajwaNK, Sidhu HS. Quantitative assessment of fluoride release and recharge ability of different restorative materials in different media: an in vitro study. J Clin Diagn Res. 2014;8(12):ZC31-4. doi:10.7860/JCDR/2014/9985.5275
8. SaxenaS, Tiwari S. Energy dispersive X-ray microanalysis, fluoride release, and antimicrobial properties of glass ionomer cements indicated for atraumatic restorative treatment. J Int Soc Prev Community Dent. 2016;6(4):366-72. doi:10.4103/2231-0762186790

9. Bagheri R, Taha NA, Azar MR, Burrow MF.Effect of G-Coat Plus on the mechanical properties of glass-ionomer cements. AustDent $J$. 2013;58(4):448-53. doi:10.1111/adj.12122

10. Rai R, Gupta R. In vitro evaluation of the effect of two finishing and polishing systems on four esthetic restorative materials. J Conserv Dent 2013;16(6):564-7. doi:10.4103/0972-0707.120946

11. Pacifici E,Bossù M, Giovannetti A, La Torre G, GuerraF,Polimeni A.Surface roughness of glass ionomer cements indicated for uncooperative patients according to surface protection treatment. Ann Stomatol (Roma). 2014;4(34):250-8.

12. Jost-Brinkmann PG. Effect of air polishing on the fluoride release of (resinmodified) glass ionomer cements and of a polyacid-modified composite resin. Clin Oral Investig. 1998;2(2):91-5. doi:10.1007/s007840050051

13. McKnight-Hanes C, Whitford GM. Fluoride release from three glass ionomer materials and the effects of varnishing with or without finishing. Caries Res. 1992;26(5):345-50. doi:10.1159/000261466

14. Upadhyay S, Rao A, Shenoy R. Comparison of the amount of fluoride release from nanofilled resin modified glass ionomer, conventional and resin modified glass ionomer cements. J Dent(Tehran). 2013;10(2):134-40.

15. Thanjal NK, Billington RW, Shahid S, Luo J, Hill RG, Pearson GJ. Kinetics of fluoride ion release from dental restorative glass ionomer cements: the influence of ultrasound, radiant heat and glass composition. J Mater Sci Mater Med. 2010;21(2):589-95. doi:101007/s10856-009-3901-3

16. KucukyilmazE, Savas S, KavrikF, Yasa B, Botsali MS. Fluoride release/ recharging ability and bond strength of glass ionomer cements to sound and caries-affected dentin. Niger J Clin Pract. 2017;20(2):226-34. doi:10.4103/11193077.178917

17. Mousavinasab SM, Meyers I. Fluoride release by glass ionomer cements, compomer and giomer. DentRes J (Isfahan). 2009;6(2):75-81.

18. Bansal R, Bansal T.A Comparative Evaluation of the Amount of Fluoride Release and Re-Release after Recharging from Aesthetic Restorative Materials: An in vitro Study. JClin Diagn Res. 2017 Apr;11(4):ZZ01]. JClin Diagn Res. 2015:9(8):ZC11-4. doi:10.7860/JCDR/2015/11926.6278

19. Dionysopoulos D, Koliniotou-KoumpiaE, Helvatzoglou-Antoniades M, Kotsanos N. Fluoride release and recharge abilities of contemporary fluoride-containing restorative materials and dental adhesives. [retracted in: Dent Mater J. 2015;34(3):410]. Dent Mater J. 2013;32(2):296-304. doi:10.4012/dmj.2012-144

20. Tiwari S, Kenchappa M, Bhayya D, et al. Antibacterial Activity and Fluoride Release of Glass-lonomer Cement, Compomer and Zirconia Reinforced Glass-lonomer Cement. J Clin Diagn Res. 2016;10(4):ZC90-93. doi:10.7860/ JCDR/2016/16282.7676

21. Kishore G, Sai-Sankar AJ, Pratap-Gowd M, Sridhar M, Pranitha K, Sai-Krishna VS. Comparative Evaluation of Fluoride Releasing Ability of Various Restorative Materials after the Application of Surface Coating Agents - An In-vitro Study.J Clin Diagn Res. 2016;10(12):ZC38-41. doi:10.7860/JCDR/2016/21980.9047

22. Ugurlu M, Ozkan EE, Ozseven $A$. The effect of ionizing radiation on properties of fluoride-releasing restorative materials. Braz Oral Res. 2020;34:e005. doi:10.1590/1807-3107bor-2020.vol34.0005

23. Tiwari S, Nandlal B. Invitro Evaluation of Fluoride Release from Hydroxyapatite Reinforced Glass lonomer with or without Protective Coating.J Jlin Diagn Res. 2016;10(4):ZC73-5. doi:10.7860/JCDR/2016/12598.7668 
24. Tiwari S, Nandlal B. Effect of nano-filled surface coating agent on fluoride release from conventional glass ionomer cement: an in vitro trial. J Indian Soc Pedod Prev Dent. 2013;31(2):91-5. doi:10.4103/0970-4388.115703

25. Guedes $\mathrm{OA}$, Borges AH, Bandeca MC, Nakatani MK, de Araujo Estrela $\mathrm{CR}$, de Alencar $\mathrm{AHG}$, etal. Chemical and structural characterization of glass ionomer cements indicated for atraumatic restorative treatment. $J$ Contemp Dent Pract. 2015;16(1):61-7.Published 2015 Jan 1. doi:10.5005/ jp-journals-10024-1636
26. Karantakis P,Helvatioglou-Antoniades M, Theodoridou-PahiniS Papadogiannis Y.Fluoride release from three glass ionomers, a compomer, and a composite resin in water, artificial saliva, and lactic acid. Oper Dent. 2000;25(1):20-5.

\section{Muhittin Ugurlu}

\section{(Corresponding address)}

Süleyman Demirel University, Faculty of Dentistry, East Campus, 32100, Isparta, Turkey. 